\title{
Flows and uses of diaspora remittances by receiving households in Guyana
}

\section{Fluxos e usos das remessas da diáspora pelos domicílios receptores na Guiana}

Hisakhana P. Corbin - PhD., Environment and Social Development; Centre for Advanced Amazonian Studies (NAEA), Federal University of Para (UFPA), Brazil; Senior Associate, Environmental Safeguards Unit, Inter-American Development Bank, USA; E-mail: hisacorbin@hotmail.com.

Luis E. Aragon - Professor and researcher, Centre for Advanced Amazonian Studies (NAEA), Federal University of Para (UFPA). Chair holder, UNESCO Chair in SouthSouth Cooperation for Sustainable Development.

\section{Resumo}

Este artigo é baseado em um caso de método misto mais amplo sobre as potencialidades e os desafios da migração e remessas para a economia da Guiana. Dados para o estudo foram coletados por meio de questionários, entrevistas, discussões em grupo, arquivos, e observações (direta e participante). Este artigo centra-se especificamente sobre os fluxos e uso das remessas monetárias e não monetárias pelas famílias guianenses que as recebem. $\mathrm{O}$ estudo também confirma uma dependência significativa de remessas por parte das famílias para satisfazer as suas necessidades básicas, o que confirma ainda mais a vulnerabilidade da economia da Guiana para responder a choques da economia dos países dos quais as remessas são remetidas. Apesar destes fluxos e da dependência evidente das remesas por parte das famílias que as recebem, uma política, que vise maximizar os benefícios para as famílias e a economia, ainda está para ser elaborada e implantada. Além de fazer sugestões esse respeito, indica-se futuros estudos, com a finalidade de fortalecer as políticas e a literatura existente sobre o fluxo, o uso e o impacto das remessas nas familias guianenses.

\section{Palavras-chave}

Domicílios. Remessas. Diáspora. Guiana.

\begin{abstract}
This article is based on a wider mixed method case study conducted with focus on the potentials and challenges of migration and remittances on Guyana's economy. Data has been augmented through the use of questionnaires, interviews, focus group discussions, archival records, and observations (direct and participant) in the study. This article focuses specifically on the flows and uses of monetary and nonmonetary remittances by receiving Guyanese households. The study also confirms a significant dependence on remittances by households to meet their basic needs, which further confirms the vulnerability of Guyana's economy in response to shocks on the economies from which remittances are remitted. In-spite of those flows and the evident dependency among households on remittances, a policy instrument, that seeks to maximize the benefits to receiving households and economy, is yet to be crafted and implemented. In addition to making recommendations in this regard, further studies are recommended with the sole aim of strengthening policies and the existent literature on the flows, use and impacts of remittances on Guyanese family households.
\end{abstract}

\section{Keywords}

Diaspora. Remittances. Guyana. Households 


\section{INTRODUCTION}

World Bank statistics show that monetary remittances to Guyana have skyrocketed following the new millennium and, in 2013, placed the country in the category of the 32 countries worldwide in which remittances account for $9 \%$ or more of their Gross Domestic Product (GDP). In 2013, inflows of monetary remittances to Guyana totaled US\$328 million.

In response to the massive flows of remittances across the world, the World Bank, the Inter-American Development Bank and the International Monetary Fund (IMF) have commissioned studies in a number of countries around the world to assess various types of remittances (CORBIN, 2013). In spite of the progress made in acquiring knowledge on the topic, very little is known about the flows of in-kind remittances (referred to as nonmonetary remittances henceforth) in the context of social and economic development and their relations with monetary remittances (WORLD BANK, 2005). In Latin America and the Caribbean (LAC), there has been significant focus on Mexico, El Salvador and Guatemala, with very little attention given to the peculiarities of English-speaking countries of the Caribbean Community (CARICOM) such as Guyana, which has lost over $56 \%$ of its total population to international migration and, simultaneously, continues to be one of the economies in LAC that is, relative to GDP, heavily dependent on remittances.

Given that monetary remittances alone have exceeded Foreign Direct Investment (FDI) and Overseas Development Assistance (ODA) to Guyana since the turn of the New Millennium, a study that focuses on the flows and uses of monetary and nonmonetary remittances by households allows a clearer understanding of their importance, and as such, could help to implement policies for maximizing the benefits of remittances. With this in mind, this paper seeks to define the Guyanese diaspora, quantify the flows of monetary and nonmonetary remittances that are remitted to Guyana, and discuss the uses of these remittances among recipient Guyanese households. Conclusions, recommendations and implications for further research are also presented.

\section{GUYANESE IN THE DISAPORA}

According to the Guyana Ministry of Foreign Affairs (2012), the Constitution and Laws of Guyana provide four means for the acquisition of Guyanese citizenship: (1) birth, (2) descent, (3) naturalization, and (4) registration. 
Therefore, it could be expected that the Guyanese diaspora consists of persons of the aforementioned categories of legal citizenship that are currently living in a foreign country. Although there is no known estimate of Guyanese beyond first generation migrants in the diaspora, it is estimated that Guyana has lost 417, 469 (56\%) of its total population to migration (PETERS, 2009, p. 9).

As Guyana continues to suffer from brain drain (CORBIN, 2009; 2013), the flows of remittances to Guyana may seems to have an immediate impact on poverty alleviation. Regarding the causes of poverty in Guyana, the Poverty Reduction Strategy Paper (PRSP) emphasizes: (1) poor economic policies prior to the Economic Recovery Programme (ERP), (2) poor governance as characterized by a non-participatory system of local government and weak regulatory and institutional support, (3) non-growth complementing infrastructure particularly in rural areas where over $70 \%$ of the population is concentrated, (4) deterioration of social services particularly in the areas of health and education (GINA, 2000).

While there is no policy framework specifically to unlock the potential of remittances that flow to Guyana to alleviate poverty, as is in the case of Mexico's Programa Iniciativa Ciudadana under which the federal, state and municipal governments of Mexico have been engaging the diaspora as an agent for social and economic development of micro-regions facing varying indices of marginalization (SEDESOL, 2005); diaspora remittances to Guyana are currently being channeled directly to beneficiaries with very little government intervention to maximize the benefits for poverty alleviation and economic growth. A political agenda for instructional change and participatory planning for local and regional development in this regard seem very restricted in spite of the size of the Guyanese diaspora, relative to the country's total population, and importance of remittances to the Guyanese economy.

\section{AGGREGATE FLOWS OF MONETARY REMITTANCES TO GUYANA}

In response to the massive emigration among Guyanese, the volume of remittances to the country continues to show an increasing trend. Statistics from the World Bank show that in 2013 Guyana was the $7^{\text {th }}$ most remittance dependent economy in Latin America and the Caribbean (LAC) (Figure 1). 
Figure 1 - Remittances as a \% of GDP of selected LAC countries, 2013

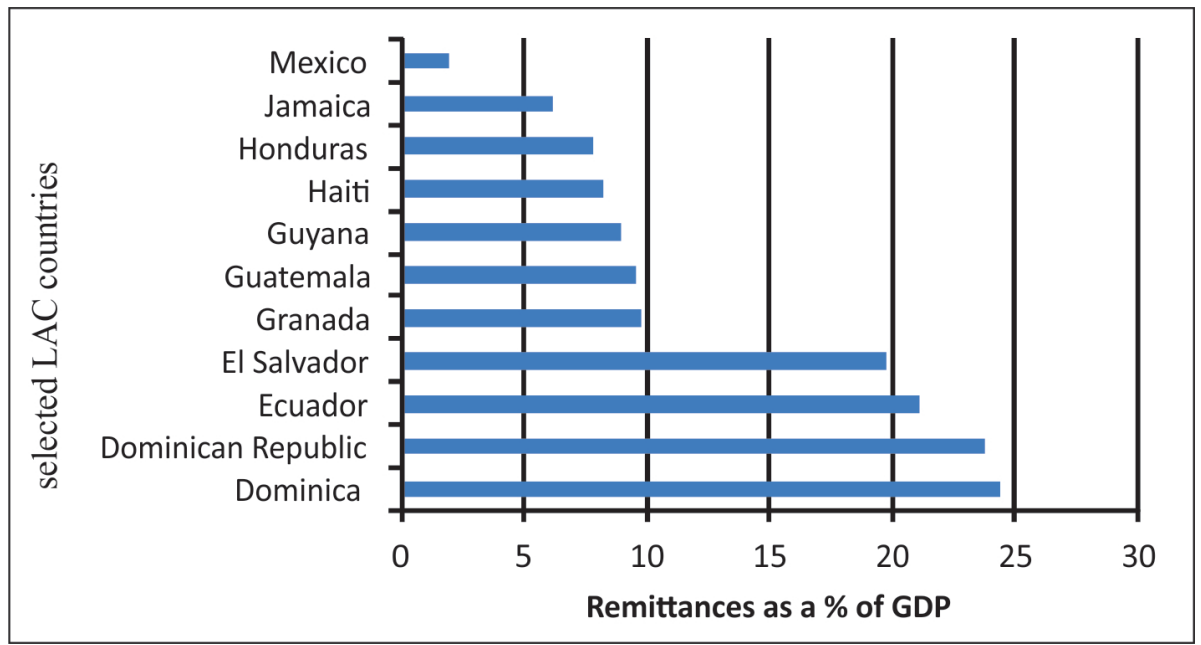

Data source: World Bank, 2014.

Data gathered form the World Bank and the United Nations datasets, shows that the volume of remittances is higher than FDI and ODA, as mentioned above (Figure 2).

Figure 2 - Official Monetary Flows to Guyana, 2000-20011

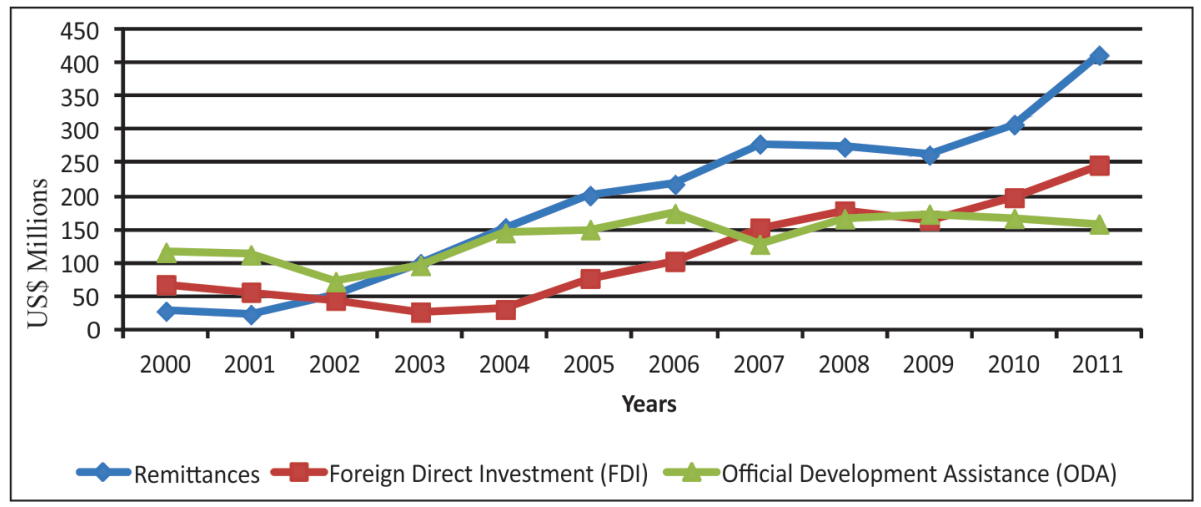

Sources: World Bank (2014); UNCTAD (2014)

Flows of remittances have continued as Guyana's economy was severely hit by a natural disaster in 2004-2005, when some $59.49 \%$ of the 2005 GDP was lost due to severe flooding (ECLAC, 2005). In 2003, monetary remittances totaled US \$ 99 million. There were significant increases to US\$ 153 million and 201 million during 2004 and 2005, respectively, perhaps in response to 
the natural disaster, which commenced during the last quarter of 2004 and continued into the first quarter of 2005. Remittances have even exceeded ODA during this worst natural disaster in Guyanese history. However, further studies would be necessary to better analyze natural disaster and the flows and impact of remittances on resilience of migrants' hometowns. A quantification of nonmonetary remittances that flowed to Guyana during that period could reveal a significantly higher value of total remittances to Guyana. Simultaneously, such aggregate could allow a clearer understanding of the migrants' propensity to remit during economic crises triggered by natural disasters.

The flows of monetary remittances to Guyana are quite unique in the sense that Money Transfer Offices (MTOs) are decentralized throughout the country, which are somewhat different from the situation that the researchers have observed in other countries in LAC. In Guyana, monetary remittances can also be transferred via commercial banks, but these are often not preferred due to a number of factors including centralization of commercial banks in urban centers and bureaucracies at commercial banks. While the exact number of money transmitters in Guyana remain unknown considering the large extent of the underground economy and the fact that these institutions are poorly regulated by the Central Bank of Guyana, information from money transmitters published in the Guyana's telephone directory (2011) registers that there are six (6) commercial banks, eight (8) Money Transfer Operations/companies/ Money Transmitters (MTOs/MTs) and eight (8) Money Exchange Cambios in Georgetown (Table 1).

Table 1 - Money Transfer Operations in Georgetown Guyana, 2011

\begin{tabular}{ll}
\hline Money Transfer Firms & Firm Type \\
\hline Laparkan Financial Services Ltd. & Non-Bank \\
Money Gram & MTO \\
Western Union & MTO \\
Ria Financial & MTO \\
Samso's Express Money Transfer & MTO \\
Uno Money Transfer (Omnex Group) LOCAL & MTO \\
Virgo & MTO \\
Solomon Shipping Company & MTO \\
Citizens Bank Guyana Incorporated & Commercial Bank \\
Demerara Bank & Commercial Bank \\
Guyana Bank for Trade \& Industry Ltd. & Commercial Bank \\
Demerara Bank & Commercial Bank \\
Republic Bank (Guyana) Ltd. & Commercial Bank \\
Scotiabank & Commercial Bank \\
A \& N Sarjoo Cambio & Cambio
\end{tabular}


Citizens Bank Guyana Incorporated

L. Mahabeer \& Son Cambio

Laparkan Financial Services Ltd.

Swiss House Cambio

Mohammed's Enterprise

Salt \& Pepper Restaurant \& Bakery Cambio

Sookraj Cambio

Sources: Guyana Telephone Directory (2011)
Cambio

Cambio

Cambio

Cambio

Cambio

Cambio

Cambio

Money Transmitters are relatively new to Guyana's economy. The period of nationalization and restricted international trade reduced inflows of foreign direct investment (FDIs) leading to extreme shortages of many essential commodities, foreign currency and, as a consequence, the proliferation of black marketing which is also known as the underground economy (FLETCHER; CULPEPPER, 2001). While assessing the proliferation of Guyana's underground economy, Thomas (2011) observed two phases. The first phase, the flourishing of the underground economy, which followed independence, was as a result of the statist economic development policies and restrictions to the flows of goods and capital, while the second phase was attributed to efforts of tax evasion and corruption that followed the Economic Recovery Programme (ERP).

The abandonment of the exchange controls and the retention of a soft limit of private capital receipts have created the favorable economic environment for the proliferation of cambios and Money Transmitters (MTs) following the ERP (FLETCHER; CULPEPPER, 2001). Committed to reduce the transaction cost by Guyanese receiving remittances, some MTs continue to decentralize their operations throughout the country. As Western Union and Money Gram offices can be found in each administrative region in Guyana, it is not surprising that together they account for more than $70 \%$ of the monetary remittance flows to Guyana (PETERS, 2009). This decentralization of operations is crucial particularly for poor countries and poor households receiving remittances, which are already in small amounts. This reduction in transaction costs to receive remittances means that remittance receiving households have additional small change to divert to consumption, savings and/or micro investments.

In 2010, monetary remittances in Guyana totaled US\$ 308 million. From a regional perspective, most money transfer offices are located along the coast, while there is very low access to such services in poorer hinterland regions such as Regions 7, 8, and 9. The Guyana Bureau of Statistics and the Inter-American 
Development Bank created the District Marginality Index $(\mathrm{EDMI})^{1}$ for the classification of Enumeration Districts according to wealth/poverty status. Higher values denote greater poverty across the respective regions (Table 2). Regions 1, 7, 8 and 9 are located in the hinterlands, have smaller proportions of Guyana's population and lower demographic densities (Table 3).

Table 2: Flows of Remittances by Enumeration District Marginality Index (EDMI), 2002

\begin{tabular}{l|c|c|c}
\hline Region & EDMI INDEX & Number of MTOs & \% of total population \\
\hline Region 1 & 2.12 to 2.13 & 0 & 3.2 \\
\hline Region 2 & 0.58 to 1.02 & 0 & 6.6 \\
\hline Region 3 & 0.30 to 0.58 & 16 & 13.7 \\
\hline Region 4 & -0.14 to 0.19 & 32 & 41.3 \\
\hline Region 5 & 0.23 to 0.30 & 5 & 7.0 \\
\hline Region 6 & -0.14 to 0.19 & 16 & 16.5 \\
\hline Region 7 & 1.02 to 1.98 & 3 & 2.3 \\
\hline Region 8 & 1.98 to 2.05 & 0 & 1.3 \\
\hline Region 9 & 1.98 to 2.05 & 1 & 2.6 \\
\hline Region 10 & -.03 to -0.14 & 0 & 5.5 \\
\hline
\end{tabular}

Sources: Guyana Bureau of Statistics (2005); Guyana Telephone Directory (2011)

Table 3 - Demographic Density, Guyana, 2012

\begin{tabular}{|l|r|r|}
\hline \multicolumn{1}{|c|}{ Administrative regions } & Population in 2012 & \multicolumn{1}{c|}{ Demographic density } \\
\hline Region 1 & $26,941.0$ & 1.30 \\
\hline Region 2 & $46,810.0$ & 7.60 \\
\hline Region 3 & $107,416.0$ & 28.60 \\
\hline Region 4 & $313,429,0$ & 140.40 \\
\hline Region 5 & $49,723.0$ & 11.90 \\
\hline
\end{tabular}

Based on statistics from the 2002 census, the following variables were used to compute this Enumeration District Marginality Index EDMI:

The proportion of adults (15 yrs of age or older) in the enumeration district (ED) who have either no education at all or did not complete primary schooling;

The proportion of adults (15 yrs of age or older) in the enumeration district who work in the primary sector;

The proportion of children (6-14 yrs of age or older) in the enumeration district who do not attend school full-time;

The proportion of dwellings in the enumeration district that report not having piped water as their main source of water supply;

The proportion of dwellings in the enumeration district that do not have a W.C. linked to sewer;

The proportion of dwellings in the enumeration district that do not report electricity as their main source of lighting;

The proportion of dwellings in the enumeration district that report their main method of garbage disposal is not garbage collection service, compost, or burying;

The average number of family members per bedroom in the enumeration district (Crowding) (GUYANA BUREAU OF STATISTICS, 2005). 


\begin{tabular}{|l|r|r|}
\hline Region 6 & $109,431.0$ & 3.00 \\
\hline Region 7 & $20,280.0$ & 0.43 \\
\hline Region 8 & $10,190.0$ & 0.50 \\
\hline Region 9 & $24,212.0$ & 0.42 \\
\hline Region 10 & $39,452.0$ & 2.30 \\
\hline GUYANA (TOTAL) & $747,884.0$ & 3.50 \\
\hline Coastland & $666,261.0$ & 9.60 \\
\hline Hinterland & $81,623.0$ & 0.60 \\
\hline
\end{tabular}

Sources: Guyana Bureau of Statistics (2014)

Hinterland regions are not the major sending regions of emigrants, and hence, receive lower volumes of remittances. Consistently, hinterland regions are plagued by higher levels of poverty and indigence (GINA, 2000). While poverty has declined in urban coastal areas in subsequent years following the ERP, statistics show that that poverty marginally declined in hinterland areas (GINA, 2000). From a regional perspective, therefore, EDMI showed wealthier households concentrated in regions 10,6 and 4, which account for the regions to which there are greater flows of monetary remittances. With the addition of region 2 , these four regions $(2,4,6$ and 10) have the larger urban centers of the country and account for $28 \%$ of Guyana's population. The remaining $72 \%$ of the population is clustered in villages mainly along the coastal belt, while a few others are scattered deep in the hinterlands.

\section{TRANSFERS OF NONMONETARY REMITTANCES TO GUYANA}

There is no known data source available for nationwide aggregate transfer of nonmonetary remittances to Guyana. Similarly, there is no known study that has assessed the spatial distribution of nonmonetary remittances from a regional perspective in Guyana. The transfer and receipt of nonmonetary remittances from abroad is observed to be a completely different process when compared to that of monetary remittances. In the case of nonmonetary remittances, household goods are shipped in barrels and boxes through a complex shipping arrangement involving shipping lines, customs brokers and agents with global networks. Currently, Guyana has the flowing of five (5) wharfs/ports located along the Demerara River in Georgetown: (1) John Fernandes Shipping, (2) Muneshweres Shipping, (3) Guyana National Shipping Corporation Limited 
(GNSCL), (4) Laparkan Shipping, and (5) Demerara Shipping Co. Ltd. Guyanese family households receive in those ports nonmonetary remittances which most commonly include: (1) Food items including rice, flour, sugar, all kinds of canned food items, preserved meats, juices etc.; (2) clothing and shoes, bags and cosmetics, and (3) electrical items including microwaves, radios, television etc.

Domestic cargo in barrels and boxes are shipped through the following agents that offer services across the USA, Canada, and the U.K and to a smaller extent, the English Speaking Caribbean. Packages that cannot be classified as barrels and boxes are classed as others. In many cases, others include items such as gas stoves, fridges, chairs, television sets, tables, beds, bicycles and so on. Once arrived at the Ports in Georgetown, households have up to three weeks to uplift their cargo, thereafter, they are required to pay a fee for storage in the storage bond (Figures 3 and 4).

There is currently a very low volume of domestic cargo/personal effects flowing to Guyana from developing countries. Based on the shipment services and networks provided by Laparkan Shipping, it seems possible that a number of countries across the English, Dutch, French and Spanish-speaking Caribbean are recipients of barrels and boxes from developed countries ${ }^{2}$ (Table 4).

In response to the global financial crisis, when many migrants in developed countries become unemployed, shipping firms such as Laparkan commenced making special offers to ensure that the diaspora could remit at least the basics to family members back home.

Figure 3 - Domestic Cargo shipped to Guyanese households at GNSCL, 2011

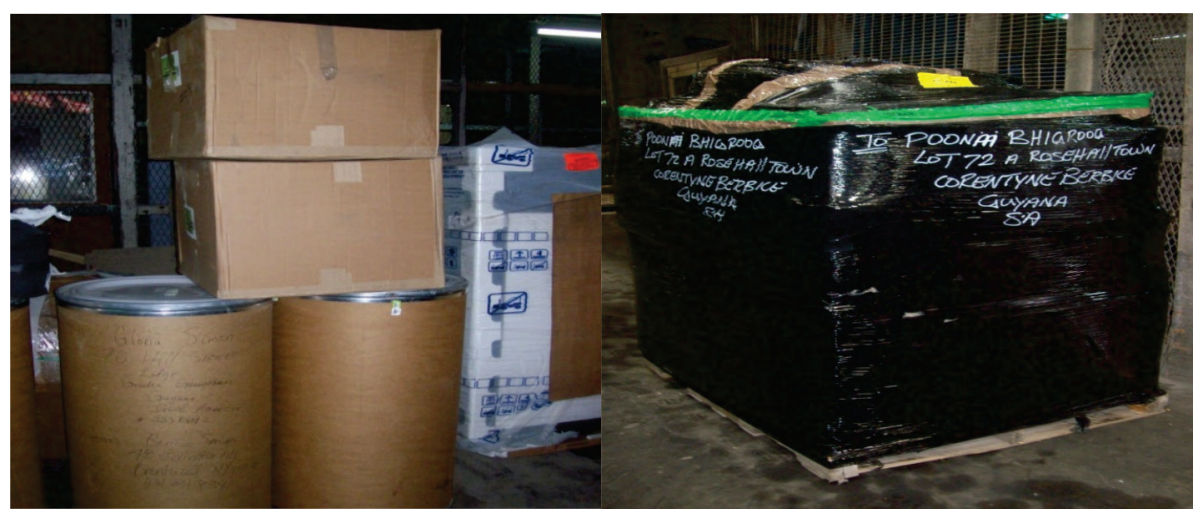

Source: Photograph by Corbin, 2011 at GNSCL.

LAPARKAN ships by air or ocean, handles customs clearance, pays duties and delivers to door at destination in Guyana, Barbados and Jamaica. 
Figures 4 - Storage bond for Barrels and Boxes at GNSCL, 2011

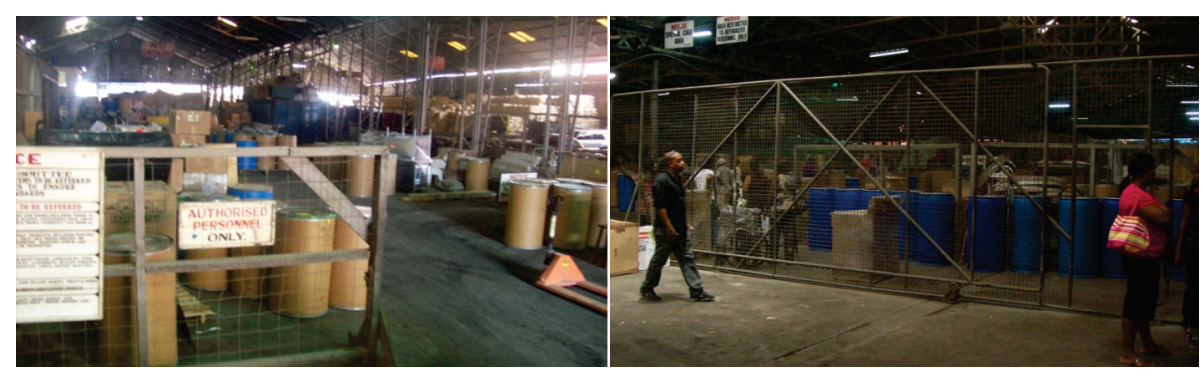

Source: Photograph by Corbin 2011 at GNSCL

Table 4 - Laparkan Guyana Shipping Services for Domestic Cargo, 1982-2012

\begin{tabular}{|c|c|}
\hline Operation & Services \\
\hline Routes & $\begin{array}{l}\text { 1. Canada } \\
\text { 2. USA: Miami, Florida, New York, New Jersey, California, } \\
\text { Georgia \& Maryland } \\
\text { 3. Dutch-speaking Caribbean: Aruba, Curacao \& Suriname } \\
\text { 4. English-speaking Caribbean: Antigua, Barbados, St. } \\
\text { Vincent, Trinidad \& Tobago, Grenada, Guyana, Jamaica, St. Lucia, } \\
\text { Dominica \& Jamaica } \\
\text { 5. French-speaking Caribbean: Haiti, Guadeloupe, Mrtinique, } \\
\text { French Guiana St. Thomas \& Dt. Croix } \\
\text { 6. Spanish-speaking Caribbean: Panama, Puerto Rico, } \\
\text { Dominican Republic \& Costa Rica }\end{array}$ \\
\hline Categories & 1. Personal Effect: Barrels and boxes \\
\hline Domestic Services & $\begin{array}{l}\text { 2. Courier service Small packages and enveloped, small boxes } \\
\text { up to } 70 \mathrm{lbs} \text { ONLY to Guyana, Trinidad \& Tobago, Barbados, } \\
\text { Suriname and Jamaica. }\end{array}$ \\
\hline $\begin{array}{l}\text { Types of shipping } \\
\text { services (for } \\
\text { domestic cargo) }\end{array}$ & $\begin{array}{l}\text { 1. Walk In } \\
\text { 2. Call in - Pick up by Laparkan } \\
\text { 3. Ship in with a third party carrier }\end{array}$ \\
\hline Pick-up services & $\begin{array}{l}\text { 1. Shipment to destination Port- at Laparkan office in destination } \\
\text { country } \\
\text { 2. Door to door shipment -to homes of receiving family }\end{array}$ \\
\hline
\end{tabular}

Source : Lakarkan (2011)

Although it is not the focus of this study, it is quite evident that there is a well established system for the flow of domestic cargo across the Caribbean. This situation is different for other countries in Latin America such as Brazil, where high import duties seem to be the major hindrances to the importation of personal effects in such circumstances as observed in Guyana and the rest of the English-speaking Caribbean. 
3.1 Domestic cargo to Guyanese family households through the Guyana National Shipping Corporation Ltd. (GNSCL) and Demerara Shipping Co. Ltd.

An analysis of data gathered from two ${ }^{3}$ of the five ports located in Georgetown, GNSCL and Demerara Shipping Co. Ltd., shows that over 29 consecutive months (January 2009 - May 2011), a total of 38,032 family households throughout Guyana received domestic cargo in barrels, boxes and other containers (Figure 5).

Figure 5 - Family households receiving non-monetary remittances, through GNSCL and Demerara Shipping Co. Ltd, January 2009- May 2011

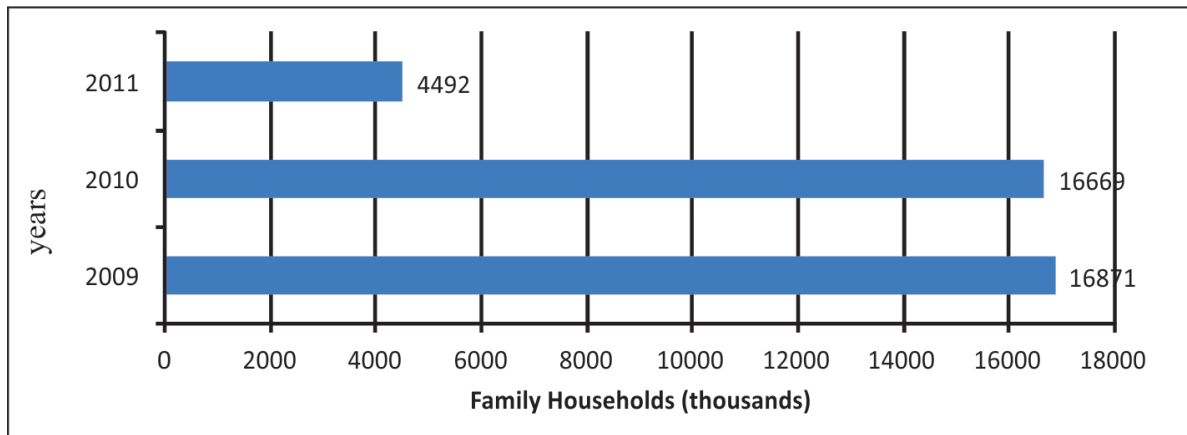

Source: GNSCL and Demerara Shipping Co. Ltd. Registers, January 2009- May 2011.

The statistics further show that an average of 16,770 families receive domestic cargo annually from these two ports. As disaggregate data was unavailable at Demerara Shipping Co. Ltd, the rest of this analysis is based on disaggregate data gathered from Port GNSCL. The annual average flow could be greater if data from the other ports was available.

An analysis of the monthly flows of barrels and boxes to Guyana reveals a seasonal pattern, where there are greater flows during the major holidays: (1) March/April for the Easter holidays, (2) July - school break/summer holidays, (3) September - back to school, when family households receive particularly goods for children attending school and (4) December, which coincides with Christmas season (Figure 6). Interviews and group discussions with households, brokers, customs officers and shipping agents all confirmed this seasonality.

Interviews and group discussions with households, brokers, customs officers and shipping agents all confirmed this seasonality.

There is no data available for the other three ports located in Georgetown, Guyana. 
Figure 6 - Seasonality of number of Barrels and Boxes shipped to Guyanese Households through GNSCL, January - December 2010

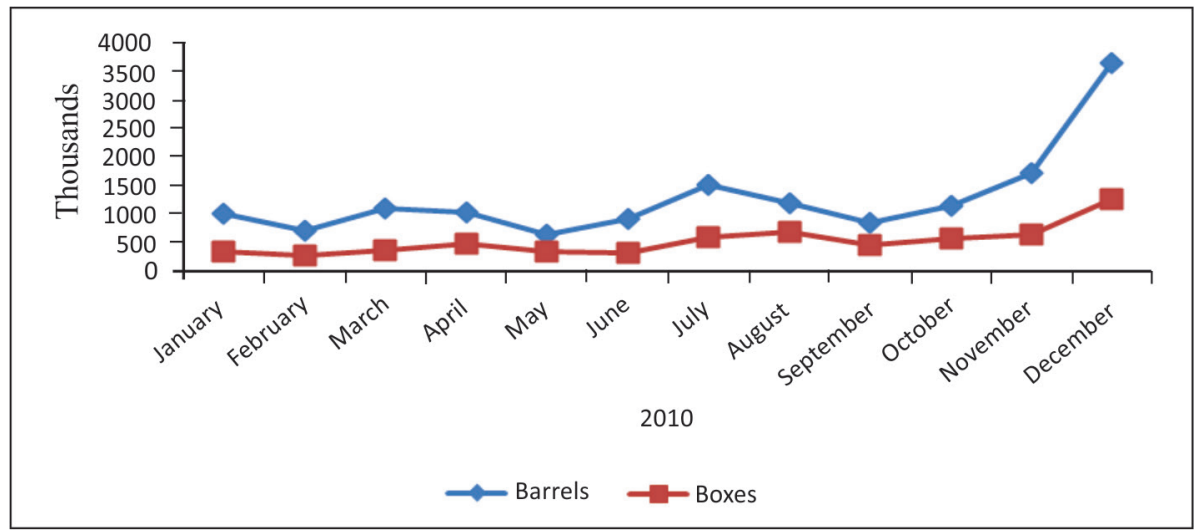

Source: GNSL Registers, January - December 2010.

The average monthly flows of barrels and boxes during 2010 were observed to be 1,279 and 513, respectively. The most frequent items sent in these barrels and boxes include: food items, especially canned food items, clothing and shoes and domestic electrical items.

\subsection{Government of Guyana Re-Migrant Programme and Land Distribution Scheme for Guyanese in the Diaspora}

In the absence of a policy framework for using remittances to enhance economic growth and development in Guyana, the government of Guyana has made institutional arrangements for the Guyanese seeking to return permanently to Guyana and transfer of their personal assets to the country under the existent Re-migrant Scheme. The Re-migrant Scheme is administered by the Ministry of Foreign Affairs in conjunction with the Guyana Revenue Authority. The Ministry of Foreign Affairs is responsible for determining and granting the status of return migration, while the Guyana Revenue Authority administers the tax exemptions (GUYANA MINISTRY OF FOREIGN AFFAIRS, 2011). The Scheme targets the following two groups of Guyanese:

- Guyanese who are eighteen (18) years and above, who has been residing legally overseas for a minimum of five (5) consecutive years and is now returning to Guyana; 
- A Guyanese student or graduate who has attended or is attending a training institution and residing overseas for a minimum of four years and is now returning to Guyana.

Time restriction for each category seems discriminatory principally against Guyanese that are not first generation migrants that have never actually visited or lived in Guyana. However, returning migrants that qualify are allowed exemption from duty and Value Added Tax (VAT) on the following: (1) a reasonable quantity of personal effects; (2) a reasonable quantity of household effects including domestic and electrical appliances; (3) a limited amount of tools of trade and (4) motor vehicles, motor cycles and leisure boats that are owned by the returning migrant at least six months before the application for re-migrant status. Documented evidence must be provided to secure exemptions (GUYANA MINISTRY OF FOREIGN AFFAIRS, 2011).

Guyanese in the diaspora are also allowed the opportunity to purchase land for residential purposes. In an effort to reduce transaction costs, the Central Housing and Planning Department, allows returning migrants and or Guyanese in the diaspora to submit applications online for the purchase of house lots for developments in the housing sector. Regarding the criteria for eligibility, the applicant must: (1) be Guyanese, (2) be 21 years and (3) not be the owner of any property in Guyana (CENTRAL HOUSING AND PLANNING AUTHORITY, 2011). Depending on its size, land price varies between US $\$ 20,000$ - US $\$ 35,000$ (CENTRAL HOUSING \& PLANNING AUTHORITY, 2011). Making lands available to Guyanese in the diaspora could lead to improvements in housing across Guyana, thus reversing the housing situation that was described as desperate after the 1980s when economic recession caused a devastating effect on the working class propelling many to squat on private and public lands, particularly in urban areas (BYNOE, 1997).

Although these current benefits exist, few Guyanese seem inclined to return permanently to Guyana (Table 5). Given the country's long history of emigration and the fact that 417,469 Guyanese reside outside Guyana, the current return, based on re-migrant applications approved over the last 7 years, is extremely low $(0,35 \%)$. 
Table 5 - Re-migrant applications approved, 2004 - 7 August 2011

\begin{tabular}{|l|l|}
\hline Year & Applications \\
\hline 2004 & 152 \\
\hline 2005 & 131 \\
\hline 2006 & 163 \\
\hline 2007 & 188 \\
\hline 2008 & 190 \\
\hline 2009 & 267 \\
\hline 2010 & 274 \\
\hline 2011 & 102 \\
\hline Total & $\mathbf{1 4 6 7}$ \\
\hline
\end{tabular}

Data source: Guyana Ministry of Foreign Affairs (2011)

\section{USES OF MONETARY AND NONMONETARY REMITTANCES BY RECEIVING FAMILY HOUSEHOLDS}

Most frequently, remittances are allocated for goods and services for basic consumption; while savings and investments remain minimal. In Guyana from a regional specific perspective, this study showed marginal increases in savings and investments in regions 4 and 6, which have higher indices of development and account for greater numbers of MTO/MTs, as indicated in Table 2. The study also reveals seasonal flows of monetary and nonmonetary remittances to Guyana. Diaspora remittances to Guyana can be thus classified into three main categories: (1) money, (2) household goods and other nonmonetary assets/ wealth, and (3) transfer of knowledge for human capital formation. Those are remitted to Guyana in the following flows:

1. Individual- individual flows,

2. Household-household flows,

3. Individual-household flows,

4. Organization-organization flows, and

5. Individual-organization flows.

In the case of Guyana remittances flow beyond the individual and/or household levels, and do include some tangible and intangibles such as knowledge 
transfers, shared property, food, clothing and household artifacts that are rarely captured and or recognized in other studies on remittances.

The seasonality corresponds to the major holiday seasons. The decentralization of these services is a positive sign that the transaction cost internalized by households would be less to uplift monetary remittances. Like other studies have confirmed, altruism is the major reason for Guyanese sending remittances to family households in Guyana. An IDB country study (PETERS, 2009) as well as another study commissioned by Guyana's Central Bank (ROBERTS, 2008) confirm that altruism is the major reason why Guyanese remit. Peters' macroeconomic analysis shows a negative relationship between remittances and investment, and also confirms that remittances to Guyana are used primarily for consumption purposes (PETERS, 2009). Similarity, Agarwal and Horowitz (2002), find that the altruistic motive for Guyanese in the diaspora to remit is very strong. Consequently, in the Guyanese context, the flow of remittances appears to be counter-cyclic, and would rise in response to economic shocks that result from episodes of natural disasters, social and political unrest that are known to affect migrants' family members in Guyana. A pro-cyclical behavior could be expected in response to a greater investment portfolio from use of remittances.

Migrants investing in housing and and/or maintenance of properties they own in Guyana is an indication that pure self-interest has some influence on migrants' propensity to remit, which acts as a form of portfolio investment that is beneficial to the migrant in the case of return migration. At present, the level of return migration to Guyana is very low, which therefore means that migrants' families continue to be major beneficiaries of funds remitted for housing. The symbiotic relationship between migrants and family households in Guyana corresponds to the Enlightened Self-interest proposition of Lucas and Stark (1985), where mutually beneficial contractual arrangement between the migrant and the household in the country of origin continue to influence investment in housing or maintenance of properties owned by migrants. While this may be true, the study finds that purse altruism is the dominant factor behind migrants' willingness to remit to Guyana. This can also be justified by the low level of return migration and the fact that Guyana is highly uncompetitive in the international labour market as expressed by low salaries offered to qualified professionals (CORBIN, 2013). For countries with high rates of return migration, 
better economic and political climates and, sound policies for accelerating the development impacts of remittances and the integration of returned migrants, we could expect that pure altruism may not be the major reason for remitting to countries of origin.

In 2010 monetary remittances to Guyana totaled US\$ 308 million. Using conservative estimates, the study further shows that the diaspora spent an additional US\$ 8,069, 655 in nonmonetary remittances that were shipped through Port GNSLC in 2010. Data from January 1 to December 31, 2010 on the flows of nonmonetary remittances, through Port GNSLC, shows that households also internalized import duties, which this study estimated in US\$374, 233 or $0.12 \%$ of monetary remittances that flowed through legal channels to Guyana in 2010. Given the bulkiness of domestic cargo, the majority of surveyed households further have incurred a cost of transportation to final destination. The transport cost varies in accordance with the distance to be travelled as well as the cost of fuel. Data from January 1 to December 31, 2010 shows that recipients of nonmonetary remittances in barrels and boxes, from Port GNSLC, incurred a transport cost of US\$ $525,357.5$ or $0.17 \%$ of monetary remittances that flowed through legal channels to Guyana in 2010. This cost is expected to be significantly higher when flows from the other ports are considered. However, the absence of data restricted such analysis. A breakdown of costs to recipients and remitters of domestic cargo through Port GNSLC in 2010 is presented in Table 6.

Table 6 - breakdown of costs to recipients and remitters of domestic cargo through Port GNSLC in 2010

\begin{tabular}{l|r|r|l}
\hline \multicolumn{1}{c|}{ Categories of costs } & Costs & Cub-totals & Grand total \\
\hline Cost of contents: & & & \\
\hline barrels $^{4}$ & $5,449,605.0$ & & \\
\hline boxes $^{2}$ & $2,620,050.0$ & $8,069,655.0$ & \\
\hline & & & \\
\hline Government Taxes: & & & \\
\hline Barrels & $199,563.0$ & & \\
\hline Boxes & $174,670.0$ & $374,233.0$ & \\
\hline & & & \\
\hline Transport Cost: & & & \\
\hline Barrels & $307,020.0$ & & \\
\hline Boxes & $218,337.5$ & $525,357.5$ & \\
\hline GRAND TOTAL US\$ & & & US \$ 8, 969, 245.5 \\
\hline
\end{tabular}

Source: Elaborated by the authors on the basis of GNSCL Registers (2009-2010). 
With monetary remittances sent to Guyana through legal channels in 2010 totaled US $\$ 308$ million, the cost to senders/remitters barrels and boxes as a percentage of total monetary remittances in 2010 was $2.6 \%$. Supposing that similar quantities of domestic cargo enter each of the 5 Ports, citrus paribus, we could expect that domestic cargo/nonmonetary/in-kind remittances across Guyana for 2010 represented an estimate of US $\$ 40,040,000$ or $13 \%{ }^{4}$ of total monetary remittances remitted by the Guyanese diaspora. To avoid double counting, customs duties and transport cost paid by remittance receiving households were not included, as those could have been already captured in official statistics on the flows of monetary remittances.

The volume of nonmonetary remittances could be much larger considering the high volume of migrants returning for vacation principally during Easter, Summer and Christmas. In 2009, the return of visitors of Guyanese origin totaled 222,468 (Guyana Bureau of Statistics, 2011), which means that almost one-half of Guyanese in the diaspora has connections with relatives back home. This also means that the transfers of nonmonetary remittances in suitcases could total an alarming amount if they were to be assessed in studies on the flows of remittances. In other words, therefore, the diaspora actually may be contributing more than what is being captured by government statistics and statistics furnished by key intergovernmental institutions, such as the World Bank, the Inter-American Development Bank, and the International Monitory Fund, that continue to advocate remittances for development. The proliferation of diaspora organizations with focus on education, health and socio-cultural development may signal a positive indication of the diaspora's commitment to return more than monetary remittances to their country of origin. It also means that migrants intend to make a wider contribution to the development of their home country rather than solely their family members left behind. This is a clear example of the channeling of collective remittances for specific uses by groups or people in the migrants' hometown. While advocating greater coordination among Guyanese diaspora organizations to better unlock the potential of remittances they remit to

\footnotetext{
With total monetary remittances sent to Guyana through legal channels in $2010=$ US\$ 308 million;

An estimate of the cost of contents in barrels/boxes that flowed through Port GNSLC in 2010 $=\mathrm{US} \$ 8,069,655.0$

Therefore, the cost to senders/remitters barrels and boxes as a \% of total monetary remittances in $2010=2.6 \%$

Assuming that equal volumes of domestic cargo/nonmonetary/in-kind remittances flowed across each of the 5 Ports Guyana, then the total nonmonetary remittances to Guyana in 2010 is estimated to be: 5 (2.6) = US $\$ 40,040,000$ or $13 \% \%$ of total monetary remittances remitted by the Guyanese diaspora.
} 
Guyana, Scott (2001) calls for an institutionalist approach for poverty reduction. Like Orozco (2003) and Peters (2009), Scott (2001) has found that diaspora institutions are making a positive contribution principally in the areas of health and education in some communities across Guyana. However, data on this dimension of remittances remains quite scarce (CORBIN, 2012).

With more than half of the Guyanese population living abroad, diaspora engagement could be a powerful tool for contributing to the development of hometown communities and the country as a whole. In spite of this potential, little institutional arrangements have been put in place to better engage the diaspora or to unlock their potentials as an alternative for accelerating development. While the necessary formal institutions between the Guyanese government, diaspora organizations and civil society seem lacking, many individuals sharing a similar background have established a number of organizations that seek to make a contribution to Guyana's development principally in the areas of health and education.

Although there is currently no policy for using diaspora remittances or engaging the diaspora in accelerating socioeconomic development in Guyana, members of the Guyanese diaspora form a number of groups and associations for contributing towards development in a number of areas. While literature reviewed indicates the presence of in excess of three hundred diaspora organizations principally in the USA, Canada and the U.K, their current existence remain uncertain or the contact information provided ten years ago has changed. A new listing of diaspora organizations located in Canada was secured through a request made to the Guyana Ministry of Foreign Affairs in 2012 shows that there are currently more than one hundred organizations formed by Guyanese in the diaspora (CORBIN, 2012).

While a few are politically-based, the majority of these organizations contribute to the area of education. Many public schools also benefit in terms of receiving text books, laboratory equipment and other educational materials for alumni associations abroad. In addition to aid from these organizations, individual Guyanese in the diaspora also contribute to knowledge transfer for developments in human capital. This is yet another way in which Guyanese in the diaspora contribute towards Guyana's development in the area of education. In most cases, linkages are established and or maintained with institutions where Guyanese have studied. These connections allow home institutions such as the University of Guyana and Cyril Potter College of Education to access highly trained Guyanese in the diaspora for human capital developments.

Novos Cadernos NAEA • v. 17 n. 2 • p. 325-347• jul-dez. 2014 


\section{CONCLUSIONS, RECOMMENDATIONS AND IMPLICATIONS FOR FURTHER RESEARCH}

Although more than one-half of Guyana's population has been lost to migration and remittances currently exceed ODA and FDI, migration and diaspora engagement have not been given any formal attention in the National Development Strategy nor the PRSPs. The absence of a migration policy that seeks to unlock the development potentials of migration is a further indication that policy and decision makers either regard migration and remittances as irrelevant or detailed case studies are unavailable for use in helping to formulate a well-defined policy.

In-spite of these weaknesses, the government's policy for providing the diaspora access to land is considered a positive factor for the development of the housing sector in general. The fact that a significant percentage of surveyed households live in houses belonging to family members or relatives outside Guyana, is a positive indication of developments in housing and in the living standards of Guyanese that depend on family members abroad. The opportunity cost of remitting money for rent is therefore the cost of building/purchasing homes to share with family members back in Guyana. While developments in the real estate industry are common in the literature reviewed, this study makes an important contribution by showing that, in the Guyanese context, the diaspora seeks primarily to provide shelter for family members and a form of security in the case of return migration, rather than to invest in real estate. The opportunity cost of remitting finance for renting can provide a clearer estimate of the contribution of remittances for improvements in the quality of life among recipient households.

The government's re-migrant programme that allows Guyanese tax exemptions on a number of domestic items is a positive effort to encourage return migration. However, the low statistics of return migration could be a signal that migrants do not find Guyana an attractive place to spend their productive years. Therefore, improvements in salaries and working conditions, ensuring political democracy, widening the benefits of this policy to foster short term return and investment in niche areas by the diaspora may be a number of unexplored alternatives for encouraging increases in the flows of the various types of remittances for accelerating economic growth through consumption, saving and investment. 
The government's policy that permits the flows of nonmonetary goods to households could have positive and negative consequences for socioeconomic development (CORBIN, 2013). While remittances are critical for poverty alleviation and improving the welfare of receiving households, they could create a dependency syndrome, thus restricting the productive capacity of labour. Given the large number of women of working age outside the labour force, higher unemployment rates among women and the consistent growth of the informal economy, an appropriate policy instrument with a focus on gender seems necessary to reverse long-term impacts on the economy.

In the light of these conclusions, a policy and planning framework for unlocking the potentials of diaspora remittances that flow to Guyanese households could include the following aspects:

- Elaborate a comprehensive policy framework on migration and development that gives significant consideration on maximizing the benefits of monetary and nonmonetary remittances flowing to households.

- Strengthen requisite institutions at the national, regional and local levels.

- Mapping Guyanese in the diaspora. A frequently updated rooster showing their socio-demographic profiles, contact information and priority areas/projects for local/regional development could be maintained by the Guyana Ministry of Foreign Affairs.

- Engage the diaspora and ensure that the necessary political, social and economic conditions are encouraging for remitting for consumption, savings and/or investments.

- Engage the diaspora and local individuals and/or groups through participatory planning for local and/or regional development.

- Ensure transparency and a proactive gender approach in the planning process.

- Embark on the necessary institutional arrangements in the financial system to encourage remitters to channel remittances through commercial banks. Simultaneously, allow recipients to use remittances as a source of income to qualify for loans for small businesses establishment across sectors of the economy.

- Request technical cooperation from institutions such as the World Bank and/or the Inter-American Development Bank that have been lending support 
in a number of areas including intuitional strengthening for maximizing the development impacts of remittances.

- Establish a system to ensure participatory planning, executing and monitoring the development impacts of specific programmes and projects that have been financed by remittances.

In order to strengthen policies and update the existing literature on the flows, use and impacts of remittances on Guyanese family households, further studies are needed in areas including:

- Cross-sectional and longitudinal studies on the flows, uses and impacts of remittances from a household perspective.

- Studies that seek to offer a greater coverage on the flows of monetary and nonmonetary remittances channelled through formal and informal channels.

- Studies that approach the flows of remittances from the perspective of remitters.

- Participatory studies that are intertwined with politics and a political agenda, thereby constituting an agenda for reform that could change the lives of remitters, recipients of remittances and researchers. Such studies should seek to provoke requisite institutional changes to address prevailing socioeconomic issues including gender empowerment, income inequality, poverty and indigence through the use of diaspora remittances.

- Studies that make greater use of data gathered from population censuses for the purpose of planning for policy formulation and development at the national, region and local levels.

\section{REFERENCES}

AGARWAL, R.; HOROWITZ, A. Are International Remittances Altruism or Insurance? Evidence from Guyana Using Multiple- Migrant Households. World Development, v. 30, n. 11, Nov. 2002.

BYNOE, M. Georgetown's urban blight. Guyana Review, no 51, p. 3-5. April, 1997.

CENTRAL HOUSING AND PLANNING AUTHORITY. Guyana land access programme. Georgetown, Guyana: s.ed. 2011.

CORBIN, H.P. Remessas monetárias e não monetárias: fluxos e integração em políticas de desenvolvimento na América Latina e Caribe. Papers do Naea, nº 324, 2013. 
Guyanese Migration and Remittances to Guyana: a case study of their potentials and challenges for Guyana's Economy. Doctoral Dissertation. NAEA/UFPA, Belém. 2012.

Migração internacional e desenvolvimento: o caso da Guiana. In: ARAGON. L. (Org). Migração Internacional na Pan-Amazônia. Belém: NAEA, 2009. p. 163-184.

ECONOMIC COMMISSION FOR LATIN AMERICA AND THE CARIBBEAN (ECLAC). Guyana socio-economic assessment of the damages and losses caused by the JanuaryFebruary 2005 Flooding. Georgetown: UNDP; Inter- American Institute for Cooperation on Agriculture (IICA), 2005.

FLETCHER, G.; CULPEPPER, D. The Impact of Money-Service Business on Monetary Policy for the Period 1989-1998. Journal Transition, University of Guyana, n. 30, p 54-78. 2001.

GINA - GOVERNMENT INFORMATION AGENCY. Guyana Poverty Reduction Strategy Paper. Office of the President, Georgetown Guyana, 2000.

GUYANA BUREAU OF STATISTICS. Guyana population and housing census 2012: preliminary report, Georgetown: GBS, 2014.

Statistical Bulletin. Georgetown, Guyana, 2011. Disponível em: www. statisticsguyana.gov.gy. Acesso em:10 nov. 2014.

Guyana population and housing census summary, Georgetown: GBS, 2005.

GUYANA. Ministry of Finance (MoF). Guyana national development strategy 20012010: A policy framework. Government of Guyana. Available online: <http://www. ndsguyana.org/>. Accessed: 12 Mar. 2011

GUYANA. Ministry of Foreign Affairs. CSME Overview. Georgetown: Ministry of Foreign Affairs. 2012.

GUYANA. Ministry of Foreign Affairs. Guyana Re-Migrant Policy. Georgetown, Guyana. Available online: <www.minfor.gov.gy, 2011>. Accessed: 30 Jan. 2011.

GUYANA TELEPHONE DIRECTORY. Yellow Pages. Georgetown Guyana: GTD, 2011

LUCAS, R. E.; STARK, O. Motivations to Remit: Evidence from Botswana, Journal of Political Economy, v. 93, n. 5, p. 901-918. 1985.

MARTINS, R. F. , RODRIGUES, C. I - Fronteiras em construção: representações de migrantes brasileiros na Guiana Francesa. NAEA/UFPA. Novos Cadernos NAEA. v. 15, n. 1, p. 333-351, jun. 2012. 
OROZCO, M. Remitting Back Home and Supporting the Homeland: The Guyanese community in the U.S. Inter-American Dialogue, Washington. 15 Jan. 2003. (Working paper commissioned by USAID GEO Project).

OROZCO, Manuel. Latino Hometown Associations as agents of development in Latin America. Inter-American Dialogue, Washington. jun. 2000.

PETERS, A. C. Macroeconomic determinants and consequences flows to Guyana. Washington, D. C.: Inter-American Development Bank, 2009. (Working Paper).

ROBERTS, D. The development impact of remittances on Caribbean economies:

The case of Guyana. Central Bank of Guyana. Georgetown, 2008.

ROCHA, G. M. A dinâmica territorial da malha político - administrativa municipal da região norte do Brasil (1988 - 2010). NAEA/UFPA. Novos Cadernos NAEA. v. 16, n. 1, p. 211-228, jan-jun. 2013

SCOT'T, M. Appendix: Report- Institutional Gaps and Human Resource Capacities for Formulating and Interpreting Poverty Reduction Strategies. Journal Transition, University of Guyana, n. 30, p 97-133. 2001.

SEDESOL - SECRETARIA DEL DESARROLLO SOCIAL. Evaluación externa del Programa Iniciativa Ciudadana 3x1 2004: Síntesis ejecutiva. Mexico: SEDESOL, 2005.

THOMAS, C. Y., et al. Revisiting the Underground Economy in Guyana. Journal Transition. University of Guyana, n. 40, p. 60-88. 2011.

UNITED NATIONS COUNCIL ON TRADE AND DEVELOPMENT (UNCTAD). Available. Available online: <http:www.unctad.org. 2011>. Access: October 27, 2014.

WORLD BANK. Leveraging Migration for Africa: remittances, skills and investments. Washington, D.C. World Bank, 2011.

WORLD BANK. Migration and Remittances Data. Available online: <www.worldbank. org/prospects/migrationandremittances >. Accessed: October 27, 2014.

WORLD BANK. Global Economic Prospects 2006: Economic Implications of Remittances and Migration: Washington D.C. World Bank, 2005. 


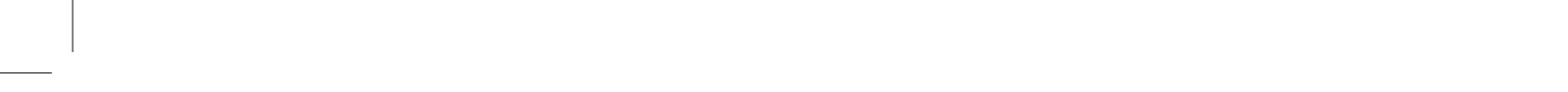

